\title{
STUDY OF COLLECTIVE PROTECTION OF SOLIDARITY RIGHTS
}

\section{ORIGINAL ARTICLE}

RIBEIRO, Danilo Miranda ${ }^{1}$

RIBEIRO, Danilo Miranda. Study of collective protection of solidarity rights. Revista Científica Multidisciplinar Núcleo do Conhecimento. Year. 06, Ed. 12, Vol. 02, pp. 152-167. December 2021. ISSN: 2448-0959, Access Link: https://www.nucleodoconhecimento.com.br/law/solidarity-rights, DOI: 10.32749/nucleodoconhecimento.com.br/law/solidarity-rights

\section{ABSTRACT}

This work seeks to build a legal analysis on the elements of the collective process for the protection of solidarity rights in the brazilian legal system. Because its provisions in laws are spaced, the study of collective protection is the problem of an airtight system that is difficult to understand. With the objective of making way for the study of the collective process and to rule out this problem, this research has as problematic the discussion about the main elements of the collective process, aiming to demonstrate that it is a coherent and harmonious procedural system. The methodology used will be bibliographic review. Thus, the work presents as a result the systematization of fundamental items to the understanding of collective protection, when addressing the legal and doctrinal provisions on the protection of solidarity rights, in order to open the field for an understanding of collective protection.

Keywords: Collective Process, solidarity rights, Civil Procedure, Principles.

\footnotetext{
${ }^{1}$ Master's degree in Human Rights and Democracy from UFPR-Federal University of Paraná. Bachelor of Law from UCSal-Catholic University of Salvador. ORCID: https://orcid.org/0000-0001-6503-9625.
}

RC: 103909

Available in: https://www.nucleodoconhecimento.com.br/law/solidarity-rights 


\section{INTRODUCTION}

Collective protection is an essential procedural instrument for the realization of social justice by protecting legal assets that do not belong only to an individual, but concern the collectivity. It turns out that the legal provisions of the institute are located in varied legislation and do not dispense with the constitutional understanding of the matter, which can be an obstacle to the coherent investigation of the collective process. In view of this problem, this research aims to offer a reflection on the essential elements of collective protection of solidarity rights, such as the concept of solidarity rights, legitimacy and competence. Thus, the collective process will be presented in a coherent and harmonious way with the guiding constitutional principles, in order to remove hermeticism that can be perceived by knowing collective protection. The methodology used will be the bibliographic review of authors who have made an important contribution to the understanding of the protection of solidarity rights.

From the constitutional perspective, the principle of due process (Art. 5, LIV, CF/88) must be interpreted by its collective dimension, by aiming at reducing formalisms to deliver to the jurisdiction an effective and fair meta individual process. The collective procedural system attributes legitimacy to several entities (ope legis), since the relevance of the protected interests evokes the responsibility of several actors to ensure the rights of a collective. In this sense, Art. 103 of the CDC places erga omnes or ultra parts efficacy for decisions prolatadas in the context of the collective process (BELLINETTI; SOUZA, 2019).

As for classification, Zavascki (2005, p. 18) divides the interests collectively into two categories. The first would be homogeneous individual interests, which would have their collective character for an empirical, contingency, not necessary question, in which there would be several subjects, but the object is divisible. The second category would cover diffuse and collective interests, constituted by those that are collective by their essence, which concern an indivisible object and an uncertain number of subjects. In relation to solitary interests, it is possible to conceive them in 
two separate areas: homogeneous individual rights and stricto sensu and diffuse collective rights.

According to Ronaldo Santos (2014), the idea of protecting the collective right is to ensure social justice for offended social groups or to legalize situations that did not have judicial protection before. For the author, the collective action had as its antecedent the Bill of Peace, which dates back to the history of the 17th century:

[...] tratava de uma autorização para o processamento de uma ação individual sob a forma coletiva, concedida nas hipóteses em que o autor requeria que o provimento da demanda englobasse os direitos de todos os indivíduos que estivessem em igual condição de litígio, para que a questão fosse tratada de modo uniforme e com vistas a evitar a multiplicação de processos (SANTOS, 2014, p. 238).

With an emphasis on the relationship of solidarity rights as fundamental rights, Hachem understands that the former bear the same elements that would be related to the fundamental rights of the three generations, not just the third, second or first generation:

Por conta da complexidade de sua natureza jurídica e estrutura normativa, todos os direitos fundamentais reúnem concomitantemente a totalidade dos traços que supostamente seriam peculiares a cada uma das gerações: (i) impõem deveres negativos ao Estado; (ii) dirigem ao Poder Público obrigações de fornecer prestações fáticas e normativas; (iii) ostentam a titularidade transindividual alegadamente exclusiva dos "direitos de terceira geração", bem como, simultaneamente, a titularidade individual pretensamente típica dos "direitos de primeira e segunda geração" (HACHEM, 2013, p. 621).

Through collective demands, the access to justice of an indeterminate collectivity or a determined group of people is amplified. The socialization and democratization of the process is pointed out as benefits of these actions, with the realization of rights and the alteration of the social reality; the possibility of correction of an illicit that would not be postulated in an individual demand before its small particular value, but which collectively has a great social impact; equality between litigants; the molecularization of demand and realization of the principle of legal certainty and legitimate expectation 
in the face of uniform decisions for similar cases; the reduction of demands in the judiciary, among many others.

More specifically, homogeneous individual interests wear the clothing of individual interests, but in the face of certain configurations of society, there is a need to be collectively protected. The nomenclature itself already translates part of the concept of this interest, according to Zavascki's lesson:

$\mathrm{Na}$ verdade, a própria denominação interesses individuais homogêneos já exibe dois enunciados: de um lado, trata-se de interesses ontologicamente individuais, não coletivos; de outro lado, que consistem numa multiplicidade de interesses individuais apresentando um determinado grau de uniformidade ou homogeneidade, sua característica mais importante (ZAVASCKI, 2005, p. 18).

According to Article 81 of Law 8.078/91, homogeneous individual interests are based on the idea of common origin, on the harmful fact that affected and violated countless people in their individuality, with no requirement of a basic legal relationship between the holders or between the parties, nor a unit as to fact or temporality (ZAVASCKI, 2005, p. 21).

Homogeneous individual interests are those that have in their origin and harmful fact that has affected a collectivity and overcomes the sphere of individual interest. Therefore, these rights have a common origin, which arise in omissive or commissive conduct of the adverse party that affects rights that escape the mere individual aspect and create the collective pretension, bringing to the discussion issues superior to the singular mere lide.

According to Zavascki's lesson (2005, p. 21), they are divisible, appropriate individually, available, transferable and represented in court by the holder himself, episodically solidarity, subjectively determined and directly reparable.

However, the characteristic of individuality does not depart from the eminent solidarity content of homogeneous individual rights. When collectively considered, these rights far exceed the sphere of particular interest of their holders. The collective 
characteristic lies not in the impossibility of being appropriate individually or their holders being indeterminable, but in the scope that the violation of society reveals (ZAVASCKI, 2005, p. 21-22). The injury to homogeneous individual interests violates social peace and promotes a great social discomfort, which generates a synergistic effect, since both are reinforced.

It would also be possible to name relevant individual interests or common interests, which was not done because homogeneity is essential for the opportunity to collectively protect the law (ZAVASCKI, 2005, p. 19).

Also in relation to solidarity rights, the categories of diffuse and collective rights stricto sensu arise. First, diffuse rights are those collective interests that are indivisible, whose holders are indeterminable and do not bear a legal relationship between them (DIDIER JUNIOR; ZANETI JUNIOR, 2014, p. 76-78). The concept of diffuse rights is found by the analysis of Art. 81, I, of the Consumer Protection Code, which are conceptualized as transindividual interests of an indivisible nature, whose holders are indeterminate and connected by a common fact.

Diffuse rights are those that belong to a collection of subjects who are indeterminate, bear indivisible rights and are linked by a situation of fact (supervening). That is, the relationship between the holders arose at a time after the injury, since there was no link between the injured at a previous time to the fact that gave cause to collective protection (DIDIER JÚNIOR; ZANETI JÚNIOR, 2014, p. 78).

Then there are the collective rights stricto sensu, which find definition in art. 81, II of the CDC. They are solidarity rights, with the difference that their holders are certain defined groups of persons, i.e. there is a basic legal relationship between the holders, who are indeterminate but determinable. That is, the difference between diffuse rights and stricto sensu collectives is that the former have indeterminate ownership and the latter have certain collective categories as holders, so people can be determined (DIDIER JÚNIOR; ZANETI JÚNIOR, 2014, p. 78-79). 
For the collective interests stricto sensu it is essential to identify which group of individuals was harmed, since the right is indivisible and the holders are those who belong to a certain category (DIDIER JÚNIOR; ZANETI JÚNIOR, 2014, p. 78).

It is worth noting that the basic legal relationship should be prior to the event of the harmful event. That is, the legal relationship between the holders does not come from the damage, as occurs in diffuse rights, but due to adherence to the labor category, association, certain society and other causes that preceded the injury (DIDIER JÚNIOR; ZANETI JÚNIOR, 2014, p. 78). In these ways, the holders of the right are fully determinable and belong to a collectivity that is individualisable.

\section{LEGITIMACY}

In situations of singular jurisdiction, almost always, the topics in question are of interest only to the parties involved in the course, without having any direct weight on persons who are not involved in the passive or active pole of the course.

Traditionally, the active legitimacy of the protection of individual interest demands an examination of ownership and dates back to the legacy of Roman Law (DIDIER JÚNIOR; ZANETI JÚNIOR, 2014, p. 79). On the other hand, the institute of law in the name of another person is not something much more current, since "[...] in the Middle Ages, there was not yet the concept of legal personality, so that it was not even possible to consider that someone was being represented by another person; ordinary legitimacy was the absolute rule" (ZAVASCKI, 2005, p. 11).

In the Brazilian legal system, the general rule is provided for in Article 18 of the Code of Civil Procedure, which places the ownership of the right as a fundamental requirement for its discussion, since the discussion of the right that belongs to the person of another belongs, subject to the cases expressly provided for by law, remains.

However, in addition to the ordinary legitimacy, portrayed by Art. 18 of the CPC, there is, on an exceptional basis, extraordinary active legitimacy, which is admitted in 
cases expressly provided by law, in which someone will plead right on behalf of the holder. In this case, there is a legislative option on cases where it will be possible to invoke the right of others in court.

Apart from the cases provided for by the legal body, the hypotheses of extraordinary legitimacy must be considered as a logical consequence of the legal system. Neves (2016) is one of the authors who comment on the possibility of extraordinary legitimacy when absent express legal permission:

Apesar de o art. 18, caput, do Novo CPC prever que a legitimação
depende de autorização expressa da lei, a melhor doutrina entende
que, além da previsão legal, também se admite a legitimação
extraordinária quando decorrer logicamente do sistema, como
acontece com a legitimação recursal do advogado em apelar do
capítulo da sentença que versa sobre seus honorários advocatícios
(NEVES, 2016, p. 188). The flexibility in relation to the rule of Art. 18 of the CPC appears as a better model to the effectiveness of the institute, proper to defend the interests of the collective. However, it is warned: flexibilization does not bring as inevitable follow-up a simpler procedure.

It is noticeable that the same right can be guaranteed to people from different social groups, which occurs with some frequency, such as when there is a violation of social guarantees. Therefore, there is a difficulty in affirming that there is a legitimacy to represent all those interested, in view of the great cultural, social or economic difference that exists among the rights holders in collective demands.

It was in this context (ZAVASCKI, 2005, p. 15) that the difficulties of defending collective interests began. If individuals are different, how do you assume that one of them has the legitimacy to demand for everyone in defense of this common interest? How can the effects of collective protection be extended on those who are not in court if it cannot be assumed what the legitimate interest of these others is? How do you demand that large groups appear in court? How to do this if group members are not even determined? 
In view of the indetermination of the holders, a great difference that exists between them and the practical difficulty of all to bring certain questions to court, the legitimation of entities that have as their purpose is the search and defense of the interests of a collectivity.

In this way, the collective legitimized are not holders of the rights that are legitimized to plead and the holders of those rights have the active ownership emptied (NEVES, 2016, p. 189). Par excellence, in Zavascki's letter (2005, p. 15), the active legitimacy in collective demands could be named as the representation of the absent.

In collective jurisdiction, there is no direct link between the ownership of the right and legitimacy, but there is a legal situation that brings the ability of certain institutions to defend interests that are not restricted to the idea of individualism, which brings the configuration of extraordinary legitimacy. In this sense:

\begin{abstract}
A legitimação ao processo coletivo é extraordinária: autoriza-se um ente a defender, em juízo, situação jurídica de que é titular um grupo ou uma coletividade. Não há coincidência entre o legitimado e o titular da situação jurídica discutida (DIDIER JUNIOR; ZANETI JUNIOR, 2014, p. 21).
\end{abstract}

The Brazilian legal system accepted the option of assuming the capacity of certain institutions to be legitimized to defend collective demands (ZAVASCKI, 2005, p. 102). That is, those legitimized for the purpose of collective actions arise from the legal establishment, as occurs in art. 5 of the Public Civil Action Law, which lists the Public Prosecutor's Office, Public Defender's Office, the Federal Union, the States, the Federal District, the Municipalities and other subjects, as representatives of the collective and able to file public civil action.

In the same movement of LACP, Article 82 of the Consumer Protection Code highlights the active legitimacy of the Public Prosecutor's Office, The Union, States and Municipalities, municipalities, public companies, foundations, mixed-economy societies or associations to defend the diffuse, collective or individual homogeneous rights of consumers. 
Furthermore, in relation to the active legitimacy for the purpose of the collective actions, Zavascki (2005, p. 132) raises a controversial aspect that surrounds the possibility of the Public Prosecutor's Office defending homogeneous individual interests, since the CRFB/88 does not confer this function on the parquet.

The constitutional vernacular, in its article 129, item III, does not list the defense of homogeneous individual interests as one of the attributions of the Public Prosecutor's Office, which has its activities linked to the constitutional text. Thus, it is possible to interpret as a legal fence the lack of determination to defend these interests (ZAVASCKI, 2005, p. 132).

Others advocate for the unrestricted legitimacy of the Public Prosecutor's Office (ZAVASCKI, 2005, p. 133). According to Article 129, item IX, of the CRFB/88, it is the function of the MP to perform functions compatible with its purpose, which includes the defense of the social and individual interests unavailable, in the light of Art. 127, the $\mathrm{CRFB} / 88$. For this current, solitary interests have a presumption of social relevance, which allows the parquet to act (ZAVASCKI, 2005, p. 133).

Finally, there is the thesis of restricted legitimacy, which emerges as a consequence of the idea that the public prosecutor would have unrestricted legitimacy, with the warning that matters of social relevance could only be those that contain congruences with the constitutional functions of the parquet (ZAVASCKI, 2005, p. 132), this based on art. 127, CRFB/88, without the effort to presume relevance to be able to bring legitimacy to the public prosecutor.

On the legitimacy of the Public Prosecutor's Office in protecting homogeneous individual interests, Zavascki concludes that the answer to this question lies through the analysis of legal costumes, because it is in the law that lies the concept of the interest of social relevance, which will ensure the active legitimacy of the parquet (ZAVASCKI, 2005, p. 132). In this way, Zavascki teaches that the interests of social relevance are constituted by: "imposition of unavailability, the direct attribution of legitimacy to the Public Prosecutor's Office for its defense and the express characterization of social relevance" (ZAVASCKI, 2005, p. 136). 
The delinde is uncontroversial. Absent the aspect of social relevance portrayed by Zavascki, there is no need to talk about the legitimacy of the parquet to act in defense of homogeneous individual interests.

Finally, it is worth highlighting the characteristics that Didier reveals in the active collective legitimation, as a regulation by Article 5 of Federal Law No. 7,347/85 and art. 82 of the CDC, being carried by entities that do not act in their own name, since the holders do not have postulatory capacity:

\begin{abstract}
Enfim, o certo é que a legitimação coletiva possui as seguintes características: a) está regulada, inicialmente, por lei (art. 5ำ da Lei Federal no 7.347/85; art. 82 do CDC etc.); b) é conferida a entes públicos, privados e despersonalizados, e, até, ao cidadão, na ação popular; c) o legitimado coletivo atua em nome próprio na defesa de direitos que pertencem a um agrupamento humano (pessoas indeterminadas, comunidade, coletividade ou g rupo de pessoas, titulares de direitos individuais abstratamente considerados, na forma do a1i. 81 do CDC e seus incisos); d) esse agrupamento humano não tem personalidade judiciária, portanto não pode atuar em juízo para proteger os seus direitos,26 cuja defesa cabe aos legitimados coletivos, que possuem legitimação autônoma, exclusiva e concorrente e simples (DIDIER JUNIOR; ZANETI JUNIOR, 2014, p. 212).
\end{abstract}

\title{
3. COMPETENCE
}

Competence is a fundamental element for the satisfaction of due process. The defense of solidarity rights occurs in favor of a collectivity, which can be separated and without any bond that unites it, which brings attention to the moment of fixation of competence.

For the fixation of territorial competence in collective demands, Neves lists seven steps necessary for the disclosure of the competent judgment. It is emphasized that the fixation of territorial jurisdiction is a consequence of the analysis of procedural legislation, in the same way as it is done in cases of singular protection, since it is a matter linked to the law treated in an isonomic way to individual protection (NEVES, 2016, p. 168). 
However, it is necessary to highlight that the legislation regulating the protection of collective rights can establish the jurisdiction originating in certain courts or atypical bodies, in the manner of what may occur in the special collective process, popular action, public civil action, collective injunction, collective warrant and action of administrative misconduct.

Due to the relevance of the measures, it is worth noting that competence in the collective sphere is regulated by the arts. 2, the Law of Public Civil Action, and 93, of the Consumer Protection Code, which establish as a criterion of territorial jurisdiction the place of damage.

Furthermore, depending on the legislation of the LACP, the competence would be territorial and functional, which raises the debate whether the competence would be due to the fora, the territorial issue, or the greater effectiveness and ease, by virtue of the functional criterion. Nevertheless, it is certain that territorial jurisdiction is absolute, which leads to its obligatory respect.

After determining the competent forum, the search for the competent judgment begins, which will be done from the laws of organization of the judiciary and the CPC. This is because the jurisdiction of the judgment is affected by territorial jurisdiction, never the other way around (NEVES, 2016, p. 186).

\section{EXECUTION OF JUDGMENT HANDED DOWN IN CLASS ACTIONS}

The basis for the execution of an individual judgment is worn by the fulfillment of a collective judgment, which must take place as a continuation of the process of knowledge, after the moment when the debtor has not complied with the sentence command. The implementation phase will be complied with by complying with a judgment, according to the circumstances provided for in Art. 515 of the CPC.

In relation to the diffuse and collective rights stricto sensu the protection of material law will be made through collective execution, which will unfold for the benefit of the community, which will be done through the aspects used in individual execution, 
without any procedural specialty due to the collective nature of interest (NEVES, 2016, p. 392-393).

From the execution may arise an injunction (prohibition of illegality) or reparatory in natura, asreversal of damages, or in cash, which, in this case, must be reverted to the legal entity of public law that faced the injury or to the Diffuse Rights Fund (art. 13 of Federal Law No. 7.347/1985) (DIDIER JÚNIOR; ZANETI JÚNIOR, 2014, p. 412).

As for legitimacy, any integral part of the active pole may promote execution, even if it has not participated in the cognition phase, according to the interpretation of Article 15 of Law 7.347, which lists as a requirement the time lapse of 60 days of the final transit so that new subjects to participate in the process for the purpose of initiating the implementation stage (DIDIER JÚNIOR; ZANETI JÚNIOR, 2014, p. 413). That is, the collective execution of diffuse or collective rights stricto sensu can be done by any extraordinary legitimized, respecting the temporal course of the final transit. This is also provided for in Art. 15 of the CBPC-IBDP and Art. 26 of the CBPCUERJ/UNESA.

It is emphasized the obligation to propose the fulfillment of judgment as an essential attribution to the parquet, in the care of collective interests (NEVES, 2016, p. 391).

However, it is worth distinguishing that the obligation of the Public Prosecutor to execute a judgment in public civil action arises after 60 days of the final judgment of the sentence, according to art. 15, of Law 7.347/85.

In relation to the popular action, the duty of the Public Prosecutor's Office to execute the sentence is pending when the citizen is inert for more than 60 days, counted from the publication of the second-degree judgment, according to art. 16, of Law 4.717/65. That is, there would be the functional duty of the moving parquet to comply with a provisional sentence, before the possibility of modification of the sentence command.

Therefore, there is also the possibility of individual enforcement in the execution of the diffuse and collective rights stricto sensu, according to Didier's lesson: 


\begin{abstract}
É também possível que a sentença proferida em um processo em que se discutem direitos difusos ou coletivos seja utilizada por um indivíduo corno título de uma execução individual, tendo em vista a extensão in utilibus da coisa julgada coletiva ao plano individual, já examinada. Obviamente, antes de executar a decisão, o indivíduo deverá proceder à liquidação do seu crédito, em que deverá demonstrar, inclusive, que é titular de um crédito (liquidação com thema decidendum mais amplo do que a liquidação individual prevista no CPC, restrita à decisão sobre o valor ou sobre a coisa a ser executada) (DIDIER JUNIOR; ZANETI JUNIOR, 2014, p. 415).
\end{abstract}

As for homogeneous individual rights, which are individual rights aggregated by their common origin, the execution will be carried out individually by the holders. In other words, the strong component of collectivity that existed in the knowledge phase was softened in the execution phase, since the individual interest will be treated as collective in the execution phase (NEVES, 2016, p. 394). As for the forum, art. 516, of the CPC imposes a binding rule, a criterion of absolute jurisdiction, which would lead to compliance with the sentence for the court that decided the case in the first degree of jurisdiction.

The interpretation of that legal provision encompasses the individual execution of a collective sentence, however, by practicality criteria Neves (2016, p. 376) defends as competent for the individual liquidation of a collective sentence the jurisdiction of the liquidator's domicile, so that there is no large concentration of cases in the district that decided on the case in the first degree of jurisdiction and less burden on the judgment creditor.

However, it should be noted that there was a presidential veto in relation to the single paragraph of Art. 97 of the CDC, which precludes the hypothesis that the forum of the execution of a collective judgment is chosen as that of the domicile of the exequente.

According to Zavascki (2005, p. 164), there is no way to consider the veto useless, since it opens the way to interpretation and reveals reasons that should be considered, since considered by legislators. 
In view of the express determination of the jurisdiction for the enforcement of judgment, it is that of the judgment which tried the case in the first degree of jurisdiction, according to Art. 516, II of the CPC, doubts about jurisdiction do not exist.

Finally, there is a controversial point in Art. 98 of the CDC, in relation to the possibility of the Public Prosecutor's Office and public agencies (legitimized of Art. 82 of the $\mathrm{CDC})$ to promote the execution of homogeneous individual interests, since the collective sphere is emptied at the time of the execution of individual interests. Highlighting Zavascki's lesson:

Quanto ao Ministério Público e órgãos públicos, não se vislumbra circunstância na qual tais entes teriam algum interesse em promover liquidação e execução específicas em favor de particulares, ainda mais mediante representação. Em consequência, é certo não possuir - Ministério Público legitimidade para promover o tratamento individualizado da sentença genérica, mas não porque ele não tem poderes para agir em nome próprio em favor das vítimas e sucessores e sim porque, nessa hipótese, não se trata de defesa de interesses sociais ou individuais indisponíveis (ZAVASCKI, 2005, p. 163).

Finally, it is interesting to note that even those who are not part of the process can complain about what was proposed in a collective judgment, since its purpose is to give concreteness to the rights of the community:

Diante disso, os instrumentos processuais utilizados para tutela dos interesses transindividuais devem ser adaptados à natureza do interesse substancial em questão, de modo a lhe proporcionar uma maior efetividade. Para tanto, algumas alterações legislativas foram feitas com a finalidade de atender esse escopo. Dentre elas menciona-se a tratativa dada à sentença coletiva, à coisa julgada e à execução de sentença coletiva. A sentença coletiva, dada sua natureza, possui um alcance diferenciado no que se refere aos indivíduos por ela albergados, podendo atingir, inclusive, aquele que não foi parte no processo, dada a extensão secundum eventum litis da coisa julgada coletiva ao plano individual (ALFREDO, BALEOTI, 2012, p. 435). 


\section{GUARDIANS OF URGENCY IN COLLECTIVE ACTIONS}

In general, the protection of urgency in collective actions does not present divergence of reasoning in relation to individual actions (DIDIER JÚNIOR; ZANETI JÚNIOR, 2014, p. 342), which brings incidence of CPC when there are the requirements set out in its art. 300 .

However, there are certain special procedures that provide for this procedural technique, such as Art. 12 of the LACP, which provides opportunities to grant early protection in the defense of certain collective interests (DIDIER JÚNIOR; ZANETI JúNIOR, 2014, p. 342).

As an example, also, Art. 4 of the LACP provides for the possibility of injunctive measures with the scope of preventing damage to the legal assets described therein. Rightly, Didier leads to the correction of the provisions of that article, since the measure would be satisfactory, since it would grant the right sought through the provocation of judicante power, not a precautionary measure:

Embora mencione expressamente a tutela cautelar, a redação do dispositivo não dá margem a dúvida: não se trata de tutela cautelar, mas, sim, tutela inibitória, que é satisfativa e visa exatamente obter providência judicial que impeça a prática de ato ilícito e, por consequência, a ocorrência de um dano (DIDIER JÚNIOR; ZANETI JÚNIOR, 2014, p. 343).

It is important to highlight certain impediments to the granting of provisional protection in class actions, such as the provisions of Article 2 of Federal Law No. 8,437/1992 and $\S 2$ of art. 22 of Law No. 12,016/2009, which limit the granting of an injunction in a collective security warrant or public civil action to the hearing of the judicial representative of the legal entity of public law, must be carried out within a maximum period of 72 hours.

Also, it is similar to what occurs for the granting of an injunction in the collective dispute for the possession of property, which is conditional on the fulfillment of the requirements set out in Art. 565 of the Code of Civil Procedure. 


\section{RECORRECTABILITY IN COLLECTIVE ACTIONS}

There is no specific recursal medium for use in class actions. What there are exceptional mentions of the recorrectability in the application in collective demands, which brings general application of the recursal system of the Code of Civil Procedure (NEVES, 2016, p. 324)

With regard to the challenge of an interlocutory decision, Art. 1,015 of the CPC lists the list of hypotheses that open the scope to instrument injury. Depending on the express permission of this article, in its paragraph XIII, other cases provided for by law allow the management of the instrument injury, in which article 19, §1, of Law $4.717 / 65$, with the provision that it is appropriate to aggravate the instrument due to an interlocutory decision in the context of popular action.

According to Neves (NEVES, 2016, p. 325), due to the collective microsystem, the aforementioned norm should be applicable in all other collective actions, which would allow the interposition of an instrument injury in any interlocutory decision that arose in a collective process.

With regard to recursive legitimacy, it is interesting to analyze that there are exceptions to the rule of 996 of the CPC, which establishes the unsuccessful party, interested third parties and public prosecutors as legitimate assets to the appeals.

It should be emphasized that Article 996 of the CPC deals with recursive interest and not recursal legitimacy, since, when dealing with an unsuccessful party, an analysis of succumbing is made, which leads to a concrete analysis of the decision that questions the recursal interest (NEVES, 2016, p. 330). Legitimacy has nothing to do with interest, because it is a legitimate part to resort to the one who wins or loses, the criterion of establishing legitimacy is totally independent of the content of the decision.

It is worth highlighting an important theme: according to the rule of Article 19, 2 , of Law $4.717 / 65$, any citizen may appeal the judgments and decisions given in the wake 
of popular action. It turns out that, depending on the rule laid down in Article 996 of the CPC, the citizen who does not compose the active pole of the course does not fit as an unsuccessful party or third party, since the right in comment in the popular action is diffuse, which removes the concept of third party interested in the sole paragraph of Art. 996, CPC. Thus, the citizen does not compose the list of subjects who have recursive legitimacy, but finds permission in the LAP to appeal.

As for the recursive effects (obstinate, translattice, expansive, substitutive, regressive and deferred) there is no particularity when generated in the collective process. Only as to the suspensive effect, it is necessary to examine the legislation concerning each action, in order to verify the absence or presence of each recursive effect referred to (NEVES, 2016, p. 332).

It is worth highlighting the legislation governing the Public Civil Action, which provides the judge with a suspensive effect on appeals with the scope of removing irreparable damage to the parties, depending on art. 14 of Law 7.347/1985, which formed the understanding that the appeals made in the scope of the Public Civil Action do not have a suspensive effect only because of their mere interposition (NEVES, 2016, p. 332). Thus, the appeal, which, as a general rule, has suspensive effects, by virtue of Article 1,012 of the Code of Civil Procedure, must comply with the requirements listed in Art. 14 of the LACP (avoiding irreparable damage aside) to prevent the judgment given in Public Civil Action from generating immediate effects.

\section{FINAL CONSIDERATIONS}

In view of the discussion carried out by this work, it is possible to observe that the text of the CRFB/88 gains strength and effectiveness with the protection of collective rights, in the manner of a search for the materialization of social guarantees that are provided for in the constitutional vernacular and can be claimed judicially.

Such an instrument is extremely interesting for social justice to be effected in a mass society, where the violation of a right can go beyond the individual sphere and reach a collectivity of people. With this reason in mind, in order to respond to the problem 
presented initially, the constitutional bias of guaranteeing solidarity rights was highlighted by conferring uniqueness to legal provisions, which seek to ensure collective rights in the achievement of the principle of social justice and due process.

By exploring the essential elements of collective protection, a harmonic system was presented that finds coherence to ensure the protection of the legal good of the whole collective. Thus, the problem of hermeticism of this procedural system was overcome, as it was approached in such a way as to discuss its constitutional matrix and its legal foundations. Therefore, what could resemble a disconnected system, because it has standardization in various legislations, is interpreted as an integrated instrument that moves to ensure rights that belong not to only one person, but to society.

\section{REFERENCES}

ALFREDO, Luciana Romaneli Rodrigues e BALEOTTI, Francisco Emílio. A sentença coletiva e a efetividade dos direitos transindividuais. Revista Jurídica Cesumar, Vol. 12, No 2, 2012.

BELLINETTI, Luiz Fernando; SOUZA, Raíssa Fabris. Obstáculos para a efetividade da tutela de direitos transindividuais por entidades sindicais em prejuízo ao efetivo acesso à justiça. Revista Cidadania e Acesso à Justiça, Florianópolis, SC, v. 5, p. 1-17, 2019.

DIDIER JUNIOR, Fredie; ZANETI JUNIOR, Hermes. Curso de Direito Processual Civil: processo coletivo. 9. ed. Salvador: JusPodivm, 2014.

HACHEM, Daniel Wunder. A dupla titularidade (individual e transindividual) dos direitos fundamentais e econômicos, sociais, culturais e ambientais. Revista de Direitos Fundamentais e Democracia, v. 14, n. 14, Curitiba, p. 618-688, jul./dez. 2013.

NEVES, Daniel Amorim Assumpção. Manual de processo coletivo. São Paulo: Método, 2016. 
SANTOS, Enoque Ribeiro dos. Processo coletivo do trabalho. 2. ed., rev., atual. e ampl. Rio de Janeiro: Forense, 2018.

ZAVASCKI, Teori Albino. Processo coletivo: tutela de direitos coletivos e tutela coletiva de direitos. Tese (Doutorado Programa de Pós-graduação em Direito) Faculdade de Direito da Universidade Federal do Rio Grande do Sul, Porto Alegre, 2005.

Submitted: December, 2021.

Approved: December, 2021. 